\title{
HAK-HAK KAUM MINORITAS \\ DALAM HUKUM ISLAM
}

\author{
Subehan Khalik \\ Fakultas Syariah dan Hukum UIN Alauddin Makassar
}

\begin{abstract}
Abstrak
Ahl al-żimmī groups constitute a minority of Muslims who gets certain privileges. This privilege because they hold very strong zimmah agreement with the Islamic State. Furthermore, aqd zimmah which they promised at the same time requiring them to pay the jizya, a payment which is paid once a year.

Żimmah agreement had an impact on their rights and obligations in the Muslim community. One of the main rights that deserve attention are their rights with respect to their ability to become an official state indefinitely unless the positions of principle and directly related to the lives of the Muslims. In obtaining their rights, these groups are required to maintain beberpa matters relating to the rules of their life in Muslim societies such as the ban on alcohol marketing and invites Muslims to taste or drink alcohol.
\end{abstract}

Keywords:

Minorities, Islamic Law, Rights

\begin{abstract}
Abstrak
Kelompok ahl al-żimmī merupakan kelompok minoritas dalam Islam yang mendapat keistimewaan tertentu. Keistimewaan ini disebabkan karena mereka mengadakan perjanjian yang sangat kuat żimmah dengan Negara Islam. Selanjutnya, aqd żimmah yang mereka ikrarkan sekaligus mewajibkan mereka untuk membayar jizyah, sebuah pembayaran yang dibayarkan sekali setahun.

Perjanjian żimmah membawa pengaruh terhadap hak dan kewajiban mereka di tengah komunitas muslim. Salahsatu hak yang patut mendapat perhatian adalah hak mereka berkenaan dengan kebolehan mereka menjadi pejabat Negara tanpa batas kecuali pada jabatan-jabatan prinsip dan berkaitan dengan hajat hidup lansung kaum muslimin. Dalam memperoleh hak mereka, kelompok ini diwajibkan untuk menjaga beberpa hal yang berkaitan dengan kaidah hidup mereka dalam masyarakat muslim semisal larangan memasarkan miras dan mengajak warga muslim untuk mencicipi atau meminum minuman keras.
\end{abstract}

Kata Kunci:

Kaum Minoritas, Hukum Islam, Hak 


\section{A. PENDAHULUAN}

$\mathrm{U}$

Tmat Islam pertamakali melebarkan sayap-sayap kekuasaan pasca terbentuknya Negara Madinah sebagai monifestasi dari penerimaan beberapa suku terhadap eksistensi Islam sebagai agama baru. ${ }^{1}$ Untuk pertamakalinya Islam diterima sebagai agama damai yang mendamaikan dan menyatukan penduduk Madinah dalam sebuah panji Negara yang bernama Madinah. $^{2}$ Secara demografi penduduk Madinah cukup beragam dari suku dan agama, namun keragaman ini telah dilebur menjadi satu kesatuan sebagai akibat dari hadirnya seorang Rasul yang mempersatukan mereka.

Sejarah mengukir bahwa penduduk Madinah melalui perjalanan hidup mereka di bawah kepemimpinan Rasulullah saw. Tanpa intrik dan perpecahan. Rasulullah senantiasa mengajarkan pola hidup damai dalam keragaman dengan Islam sebagai landasan utama negara sekaligus menjadi azas berdirinya Madinah. ${ }^{3}$ Konsekwensi dari pemilihan ini berakibat pada pola penerimaan azas ini terhadap kehadiran suku maupun agama lain di tengah kaum muslimin. Perkembangan umat Islam pada masa Rasul telah melampaui banyak wilayah dan daerah dan dalam perluasan wilayah ini terdapat beberapa penganut agama yang turut serta berafiliasi dengan kaum muslimin setelah mereka ditundukkan. Kesediaan mereka untuk bergabung bersama kaum muslimin dalam sebuah Negara inilah ang menimbulkan aspek hukum baru yaitu kehadiran warga Negara non muslim di tengah-tengah kaum muslimin. Oleh Rasul, percampuran suku, agama dan ras ini diselesaikan dengan mengadakan pengelompokan sebagaimana difahami oleh beliau dari ayat-ayat Alquran yang mengisyaratkan tempat dan eksistensi non muslim ini.

Sejarah telah mencatat bahwa Rasulullah mengadakan pemungutan jizyah setahun sebelum Rasulullah wafat tepatnya pada tahun 9 Hijriyah. Pengenaan pungutan ini dijatuhkan terhadap kelompok Kristen Najran yang berada di luar kota Madinah. ${ }^{4}$ Peristiwa ini selanjutnya menjadi tonggak bagi sahabat Rasulullah yang berkuasa pasca wafatnya Rasul untuk menentukan kebijakan mengenai eksistensi non muslim di Negara Islam Madinah.

Jizyah merupakan pajak atas jaminan keselamatan dan kebebasan bergerak orang-orang non muslim di Negara Islam. Orang-orang non muslim yang memilih untuk menjadi pembayar jizyah ini dinamai żimmī atau ahlu al- żimmah. ${ }^{5}$ Mereka

${ }^{1}$ Tamim Ansary, A History of the World through Islamic Eyes; diterjemahkan oleh Yulianto Liputo dengan judul Dari Puncak Bagdad; Sejarah Dunia Versi Islam, (Cet. I, Jakarta: Penerbit Zaman, 2010), h. 6573.

${ }^{2}$ Lihat secara seksama isi piagam Madinah dalam Ibn Hisyām, Al-Sīrah al-Nabawiyyah, Tahqīq: Musțafa al-Saqa', Jilid 1, (Mesir: Musțafa al-Bābi al-Hilyi, Cet. 2, 1375 H/ 1955 M), h. 501. Lihat juga dalam: Saifurrahman al-Mubarakfury, Sīrah Nabawiyyah, (Jakarta: Pustaka al-Kausar, Cet. 19, 2005), h. 255.

${ }^{3}$ Lihat, Munawir Sjadzali, Islam dan Negara, (Cet. V; Jakarta: UI Press, 1993), h. 8-20.

${ }^{4}$ Meski demikian sebagian kalangan menilai bahwa pemberian suku Najran tersebut bukanlah jizyah melainkan pemberian dalam bentuk sedekah; Lebih lanjut lihat: Hamka Haq, Islam Rahmah untuk Bangsa, (Cet. I; Jakarta: PT. Wahana Semesta Intermedia; 2009), h. 226-227.

5 Yusuf al-Qarḍāwi, Ghair al-Muslimīn fì al-Mujtama' al-Islāmiy, (Kairo: Maktabah Waḥbah, Cet. ke-3, 1413 H/ 1992 M), 7. 
secara hukum mendapat perlindungan oleh hukum Islam untuk hidup aman di tengah kaum muslimin, bahkan kaum żimmì ini mendapat peluang untuk menduduki jabatan tertentu. Di balik itu, ternyata sahabat juga beragam dalam memberi perlakuan kepada kaum żimmī sebagaimana tergambar dengan sikap Khalifah 'Umar bin Khattab terhadap kaum ini atas dasar perintah yang ia fahami dari ayat Alquran.

Berangkat dari latar belakang masalah di atas, tulisan ini akan membahas tentang; Bagaimana konsep hukum Islam tentang hak-hak kelompok minoritas $\dot{z} i m m \bar{\imath}$ dengan sub masalah; Siapa saja kelompok Żimmī dalam hukum Islam dan Bagaimana bentuk perlindungan hak kaum minoritas żimmī dalam hukum Islam.

\section{B. PEMBAHASAN}

\section{Ahl al-Żimmī dalam Hukum Islam}

Secara bahasa ahl bermakna suku, kabilah, dan atau sanak family. ${ }^{6}$ Jika kata ini disandarkan kepada kata tertentu semisal Rajul menjadi (ahl al-Rajul), maka kata ini bisa bermakna bahwa orang yang mengurusi urusan tersebut. Jika kata ini disandarkan kepada Nabi, maka kata ini bermakna umat dari Nabi tersebut dan jika disandarkan dengan kata al-amr (ahl al-amr), maka kata ini bermakna pihak atau orang yang bertanggungjawab mengurusi urusan tersebut. ${ }^{7}$

Kata żimmah merupakan kata jadian dari kata kerja zamma-yazummu yang berarti orang memiliki perjanjian dan tanggungan (al-kafālat wa al-dāmin). ${ }^{8}$ Wehr mendefinisikan żimm $\bar{\imath}$ atau zimma sebagai perlindungan (protection), covenant of protection, safeguard, guarantee, security of life and property. Sementara Ahl al-żimmah didefinisikan sebagai seorang non muslim yang bebas (free non-muslim) untuk hidup/tinggal di negara-negara muslim (berdasar syariat Islam), menikmati perlindungan (protection) dan keamanan (safety) dengan membayar pajak modal (capital tax). ${ }^{9}$ Dengan demikian, pengertian ahl al-żimmah secara bahasa adalah sekelompok golongan yang mengadakan perjanjian untuk menjadi bagian yang ditanggung dan memiliki ikatan dengan suatu kelompok masyarakat yang dijaga dan dilindungi.

Kata żimmī menurut Abdullahi Ahmed An-Naim merujuk kepada perjanjian antara pemerintahan umat Islam dalam Negara kepada ahlu al-kitāb dalam rangka pemberian jaminan keamanan atas diri, harta serta kebebasan melakukan ajaran ajaran agama mereka dalam lapangan privat. ${ }^{10}$ Hal senada juga dikemukakan oleh

\footnotetext{
${ }^{6}$ Muhammad Murtaḍa al-Husaini al-Zabidi, Tāj al-'Arūs min Jawāhir al-Qāmūs, Jilid 28, (Kuwait: Hukūmah al-Kuwait, 1385 H/ 1965 M), h. 40.

${ }^{7}$ Ibn Manżūr, Lisān al- 'Arab, Jilid 3, (Kairo: Dār al-Hadīì, 2003),h. 523.

${ }^{8}$ Al-Ṭāhir Ahmad al-Zawi, Al-Qāmūs al-Muhịt , Jilid 2, (Saudi: Dār 'Alam al-Kutub li al-Nasyr wa alTawzī', 1417H/1996M), h. 268.

${ }^{9}$ Hans Wehr,. English Arabic Language Dictionaries. (Itacha New York: Spoken Language Service, Inc. 1976), h. 312

10 Abdullahi Ahmed An-Naim,. Islam dan Negara Sekuler: Menegosiasikan Masa Depan Syariah. (Bandung: Mizan, 2007) h. 201
} 
Abdul Kadir Zaidan bahwa żimmī merupakan komunitas non muslim yang mendapat jaminan khusus untuk hidup dalam perlindungan kaum muslimin dengan perlindungan dan keamanan serta tempat tinggal. ${ }^{11}$

TM. Hasbi Ash Shiddieqi dan Hamka Haq kemudian memberi penekanan bahwa terdapat perbedaan mendasar antara kelompok mu'āhidūn dengan kelompok ahlu al-kitāb yang terkategorisasi sebagai żimmī. Kelompok mu'āhidūn adalah kelompok ahlu al-kitāb yang telah hidup bersama dengan kaum muslimin di Madinah ketika Rasul saw. Mendirikan Negara Madinah, sedang kelompok ahlu alkitāb kedua adalah mereka yang berada di daerah taklukan kemudian melakukan perjanjian damai dengan kaum muslimin dan mereka kemudian diwajibkan membayar jizyah maka mereka inilah yang dimaksud sebagai ahl al-żimmah. ${ }^{12}$

Uraian di atas memberi pengertian singkat bahwa żimmī merupakan kelompok non muslim yang berkedudukan pada Negara atau daerah taklukan yang kemudian menyerahkan diri kepada kaum muslimin untuk mendapat perlindungan. Mereka kemudian dibebani pembayaran atas jaminan tersebut yang kemudian dinamakan jizyah. Identitas żimmì tdk berlaku terhadap kaum non muslim yang telah mengikat perjanjian damai dengan Rasulullah saw. Pada awal Islam lewat perjanjian piagam madinah.

Ahl al-Kitāb dalam perkembangan selanjutnya, identik pula dengan term kafir. Setidaknya penggunaan istilah ini memiliki kesamaan makna terhadap pengertian dasar ahl al-Kitāb. Kelompok ini terdiri dari orang Yahudi dan Nasrani, sebagaimana difahami dari QS. Al-Bayyinah : 1 dan QS. Al-Taubah : 29 :

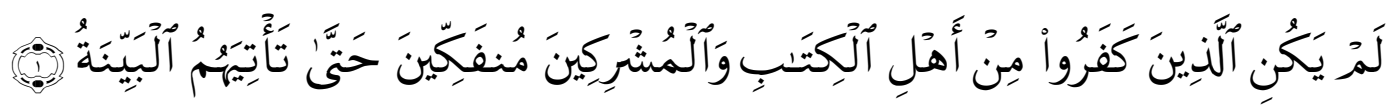

Terjemahnya:

Orang-orang kafir yakni ahli Kitab dan orang-orang musyrik (mengatakan bahwa mereka) tidak akan meninggalkan (agamanya) sebelum datang kepada mereka bukti yang nyata, ${ }^{13}$

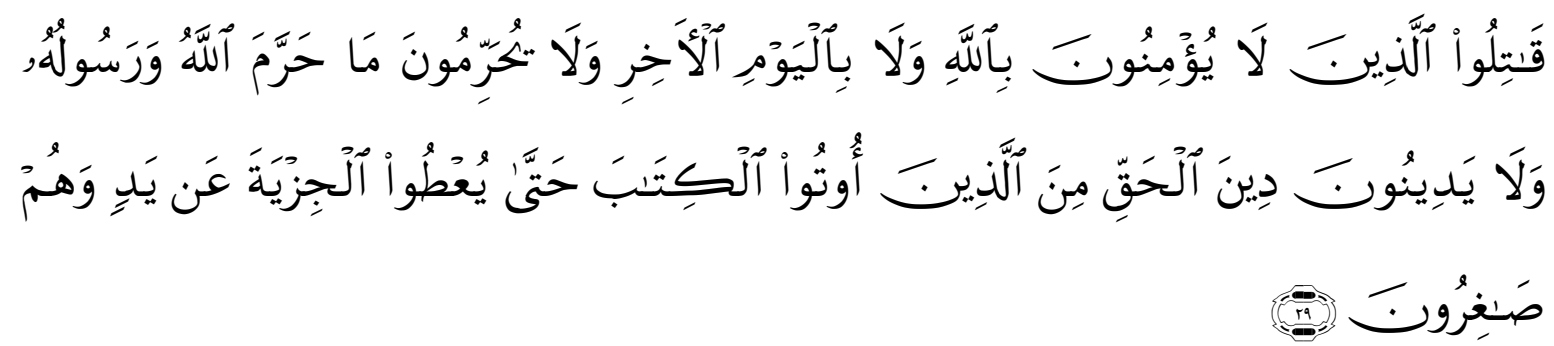

Terjemahnya :

Perangilah orang-orang yang tidak beriman kepada Allah dan tidak (pula) kepada hari Kemudian, dan mereka tidak mengharamkan apa yang diharamkan oleh Allah dan RasulNya

11 Nurcholis Madjid, Zainun Kamal dkk,. Fiqih Lintas Agama: Membangun Masyarakat InklusifPluralis. (Jakarta: Yayasan Wakaf Paramadina dan The Asia Foundation, 2004), h. 145-146

${ }^{12}$ Hamka Haq,. Konsep Zimmi dalam Islam dalam, Lutfi Asyaukanie, Wajah Liberal Islam di Indonesia. (Jakarta : JIL, 2002). h. 60-61

${ }^{13}$ Kementerian Agama RI., Alquran dan Terjemahnya (Semarang, PT. Karya Toha Putra, 1998), h. 
dan tidak beragama dengan agama yang benar (agama Allah), (yaitu orang-orang) yang diberikan Al-Kitab kepada mereka, sampai mereka membayar jizyah[638] dengan patuh sedang mereka dalam keadaan tunduk. ${ }^{14}$

Menurut Harifuddin Cawidu, term kafir secara bahasa bermakna menutup, sedang menurut istilah, adalah segala perbuatan menutup-nutupi kebenaran dan nikmat dalam arti Tuhan sebagai sumber kebenaran begitupula ajaran-ajaran-Nya yang disampaikan oleh Rasul kepada umat manusia. ${ }^{15}$ Jika kemudian para ahl al-kitāb masuk dalam term kafir sebagaimana digambarkan dalam ayat1 QS. Al-Taubah, maka terjadi korelasi yang sangat dekat antara term żimmī ahl al-kitāb serta kafir.

Kekafiran dalam Alquran dikelompokkan dalam tujuh kelompok meliputi; 1). Kekafiran dalam arti pengingkaran, baik terhadap eksistensi Tuhan beserta RasulNya beegitupula terhadap eluruh ajaran agama-Nya, biasa dinamai kufr 2). Kekafiran dalam bentuk pengingkaran terhadap kebenaran ajaran agama Tuhan walaupun yang bersangkutan telah tahu bahwa apa yang diingkari tersebut dalam sebuah kebenaran, biasa dinamai kafir juhd 3). Kekafiran dalam bentuk pengakuan terhadap Tuhan dan Rasul serta ajaran agama-Nya dengan lidah, namun mengingkarinya dengan hati. Biasa disebut dengan kufr nifāq. 4). Kekafiran dalam bentuk mempersekutukan Tuhan dengan lainnya dan menjadikan sesuatu selain Tuhan sebagai sesembahan, biasa dinamai kufr syirik. 5). Kekafiran dalam bentuk pengginaan nikmat Tuhan pada hal-hal yang tidak semestinya dan diridai-Nya, biasa dinamai kufr nikmah. 6). Kekafiran dalam bentuk kembali menjadi kafir sesudah beriman atau keluar dari Islam, biasa dinamai kufr murtad. 7). Kafir ahli kitab; yakni non Muslim yang percaya kepada Nabi dan kitab suci yang diwahyukan Tuhan kepada Nabi. Kelompok yang terakhir inilah yang menurunkan beberapa term lain perkaitan dengan term kafir sebelumnya, semisal; Kāfir Harbi, Kāfir Kitābi, Kāfir Mu'āhad, Kafir Musta'man, Kafir Zimīi, dan Kafir Riddah. ${ }^{16}$

Ulama fikih telah membagi non-Muslim dalam dua kelompok besar yaitu; ahl al-'Ahdi dan ahl al-Harbi. Pembagian ini difahami dari penjelasan dalam QS. AlMumtahanah ayat 8-9 sebagai berikut:

${ }^{14}$ Kementerian Agama RI., Alquran dan Terjemahnya (Semarang, PT. Karya Toha Putra, 1998), h. 366.

${ }^{15}$ Harifuddin Cawidu,. Konsep Kufr dalam Al-Qur'an. (Jakarta: Bulan Bintang, 1991) h. 31. h. $156-157$

${ }^{16}$ Lihat Harifuddin Cawidu Konsep, h. 33; Nurcholis Madjid, Zainun Kamal dkk, Fiqih Lintas Agama, 


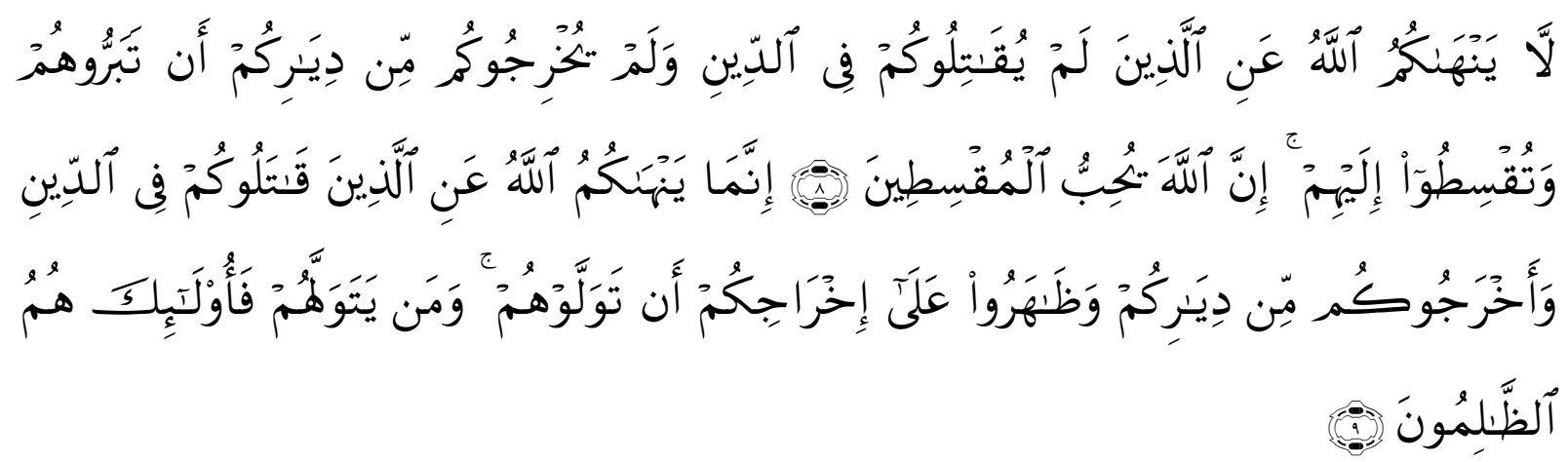

Terjemahnya :

8. Allah tidak melarang kamu untuk berbuat baik dan berlaku adil terhadap orang-orang yang tiada memerangimu Karena agama dan tidak (pula) mengusir kamu dari negerimu. Sesungguhnya Allah menyukai orang-orang yang berlaku adil. 9. Sesungguhnya Allah Hanya melarang kamu menjadikan sebagai kawanmu orang-orang yang memerangimu Karena agama dan mengusir kamu dari negerimu, dan membantu (orang lain) untuk mengusirmu. dan barangsiapa menjadikan mereka sebagai kawan, Maka mereka Itulah orangorang yang zalim. ${ }^{17}$

Yusuf Qarḍawi menggaris bawahi pembagian ini dengan memberi penjelasan bahwa semua non-Muslim yang menempati area Dār al-Harb adalah mereka yang secara kasat mata menyatakan pertentangan dan peperangan kepada kaum muslimin. Bentuk perlawanan lainnya adalah dengan tidak mengakui keberadaan kaum muslimin dan pemimpin mereka. Mereka biasa terdiri dari hanya non-muslim saja atau juga terdiri dari kelompok musyrik. ${ }^{18}$

Pada bagian lain fukaha juga mengelompokkan ahl al-'Ahdi dalam tiga golongan besar berdasarkan posisi geografis dan sikap mereka terhadap kaum muslimin. Mereka adalah; pertama, ahl al-żimmah, ahl al-hudnah dan ahl-Āmān. ahl alżimmah adalah mereka yang bermukim di Negara Islam dan mengikuti aturanaturan Negara Islam setelah mereka terlebih dahulu mereka mengadakan perjanjian żimmah yaitu dengan membayar sejumlah pajak untuk perlindungan mereka. Mereka memiliki hak-hak sebagaimana layaknya kaum muslimin dalam berinteraksi sekaligus mendapat perlindungan permanen. Kedua, ahl al-hudnah yaitu golongan yang mengadakan perjanjian gencatan senajata dengan kaum muslimin. Mereka tidak bertempat tinggal di wilayah kaum muslimin, namun tetap mengikat perjanjian untuk tidak saling serang untuk jangka waktu tertentu. Glongan ini tidak dilindungi secara angkatan bersenjata oleh kaum muslimin, namun kaum muslimin tetap memiliki ikatan yang baik dalam hubungan ini. Kelompok ini tetap diminta untuk menjaga perjanjian antara keduabelah pihak. Ketiga; ahl al-Āmān, Adalah

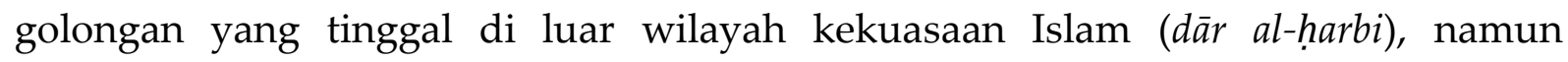

${ }^{17}$ Kemenag RI., h. 1125.

18 Yusuf al-Qardhawi, Fikih Jihad: Sebuah Karya Monumental Terlengkap tentang Jihad menurut alQur'an dan Sunnah, Terj. Irfan Maulana Hakim, (Bandung: Mizan, 2010), 751 
melakukan perjanjian untuk mendapatkan jaminan perlindungan keetika mereka berdiam di daerah teritorial kaum muslimin untuk jangka waktu tertentu. ${ }^{19}$

\section{Hak dan Kewajiban ahl al-Żimmi dalam Islam}

Ketika seorang ahl al-kitāb telah mengadakan perjanjian żimmah dengan pemerintahan kaum muslimin maka ia akan mendapatkan perlindungan terhadap harta dan jiwa mereka. Dalam konteks ini, perlindungan bermakna internal dan eksternal. Perlindungan internal berupa penghindaran non muslim dari macam gangguan dan intimidasi dari kaum muslimin. Perlindungan eksternal dimaksudkan pada proteksi kaum muslimin terhadap ahl al-kitāb dalam menghadapi ancaman dari musuh mereka, juga terhadap musuh kaum muslimin. Perlindungan ini seketika menjadi dasar perlakuan kaum muslimin terhadap mereka sekaligus menjadi tolok ukur perlindungan kaum muslimin kepada kaum minoritas dalam lingkup bermasyarakat.

Hak-hak ahl al-zimmi dalam beberapa literature dicantumkan bahwa seidaknya terdapat lima hak fundamental mereka sebagai berikut;

1) Perlindungan keamanan; Konteks ini meliputi perlindungan terhadap ahl alzimmi yang bersifat internal dan eksternal. Perlindungan ini berlaku terhadap jiwa dan harta mereka. Dalam pemahaman Yusuf Qardawi setelah mengutip pendapat Ibn Hazm menyatakan bahwa jika orang-orang kafir datang ke negeri Islam dan mengusik ketenangan kaum muslimin berikut orang-orang yang berada dalam perlindungan mereka, maka wajiblah kaum muslimin membela mereka secara keseluruhan. Perlindungan dimaksud dalam bentuk totalitas dan tidak berfihak, sebab kaum muslimin beserta orang-orang yang berada dalam perlindungan mereka adalah satu. ${ }^{20}$ Konteks ini pulalah yang menjadi pegangan Ibnu Taimiyah utuk menolak tawaran Timur Lenk ketika terjadi penaklukan Baghdad oleh tentara Mongol. Tentara Mongol berkeinginan melepaskan tawanan muslim saja. Ibnu Taimiyah selaku panglima perang kaum muslimin ketika itu secara tegas mensyaratkan agar tawanan non muslim yang berada dalam perlindungan kaum muslimin ikut dilepas jika Timur Lenk berfikir untuk melepas tawanan perangnya. ${ }^{21}$

Dapat disimpulkan bahwa perlindungan angkatan perang Islam terhadap ahl alżimmah merupakan perlindungan yang konsisten dan tidak berpihak atau memilih. Jaminan perlindungan seperti ini adalah jaminan yang sangat kuat difahami dari ajaran suci Alquran dan Sunnah Rasul. Jika ditelaah kembali terdapat beberapa landasan formal seputar sikap perlindungan terhadap ahl al-

${ }^{19}$ Lihat masing-masing; Al-Syadzili al-Qalibi, Ahl al-Zimmah fì al-Haḍārah al-Islāmiyah, (Beirut: Dār al-Gharb al-Islāmi, 1998), 27.; Ja'far 'Abd al-Salām dan Ahmad al-Syaikh, Al-Muslimūn wa al-Ākhar: Usus li Tabādu al-Hiwār wa al-Ta 'āwun al-Silmi, (Kairo: Rābițah al-Jāmi'ah al-Islāmiyah, 2006), 91.

20 Yusuf al-Qarḍawi, Al-Halāl wa al-Harām fì al-Islām, (Kairo: Maktabah Wahbah, Cet. 22, 1997 M), 292.

${ }^{21}$ Yusuf al-Qarḍāwi, Ghair al-Muslimīn fì al-Mujtama' al-Islāmiy, (Kairo: Maktabah Wahbah, Cet. ke3,1992 M), 8-9 
żimmī termasuk di dalamnya kelompok non ahl al-kitāb yang dikelompokkan menjadi ahl al-żimmah. Hadis Nabi yang dikutip dalam kitab Muwața Malik sebagai berikut:

Disampaikan kepadaku dari Malik dari Ja'far ibn Muhammad dari bapaknya, bahwasannya Umar ibn Khattab RA menyebut Majusi. Lalu ia berkata: 'Saya tidak tahu bagaimana saya harus berbuat tentang urusan mereka.' Maka Abd alRahman ibn 'Auf berkata: 'Saya bersaksi, sungguh saya telah mendengar bahwa Rasulullah SAW bersabda: Perlakukanlah mereka (orang-orang Majusi) seperti ahli kitab'. ${ }^{22}$

Inilah landasasn formal memberlakukan hukum yang sangat kuat mengenai keberadaan ahl al-żimmah yang terdiri dari golongan ahl al-kitāb maupun kelompok lainnya.

2). Kebebasan Beragama;

Konteks ini memberikan bentuk kebebasan bagi ahl al-zimmi dalam melakukan peribadatan agama mereka di tengah-tengah kaum muslimin. Sebuah kebebasan yang telah ada secara fundamental dalam Islam sebagaimana difahami dari ayat Alquran dalam QS. Yūnus: 99, QS. al-Kahfi: 29, dan QS. al-Kāfirūn: 6. Kebebasan beragama yang sebelumnya telah ada dan berlaku di kalangan internal kaum muslimin.

Fukaha memaknai kebebasan beragama itu dengan memberikan kebolehan ahl al-żimmī melaksanakan ibadah agama mereka secara bebas, namun demikian mereka tetap dibatasi oleh batasan menyebarkan agama mereka ke kalangan muslim. Hal yang sama juga berlaku terhadap penggunaan simbol-simbol agama mereka di tengah kaum muslimin. Menurut Ibnu al-Qayyim al-Jauzī dengan mengutip sebuah pernyataan sahabat, Umar bin Khattab memerintahkan kaum żimmī agar mereka menjaga sikap dan perilaku mereka di tengah kaum muslimin. Mereka dihimbau untuk tidak lagi membangun gereja-gereja mereka yang telah rubuh ataupun membangun di sekitar bangunan gereja itu tempat bermukin untuk para rahib. Selengkapnya riwayat tersebut;

${ }^{22}$ Malik ibn Anas, Al-Muwațta', Juz: 2, (T. T: Muassasah Zayid ibn Sulman al-Nahyan, Cet. 1, 1425), 
قال عبدالله بن الإمام أحمد: حدثني أبو شرحبيل الحمصي عيسى بن خالد قال: حلثني عمر

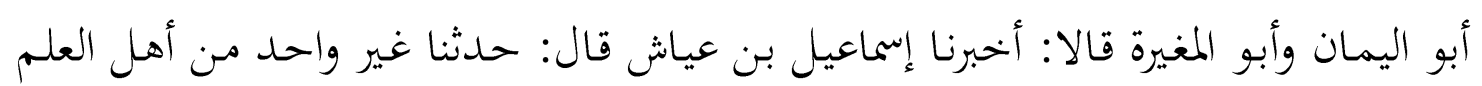

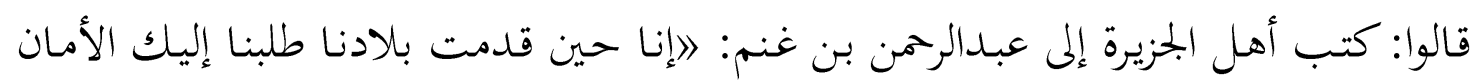

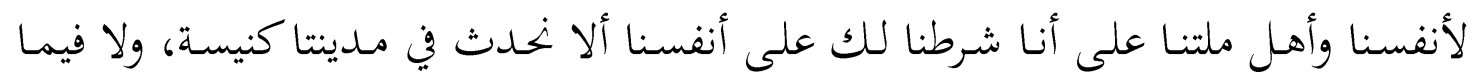

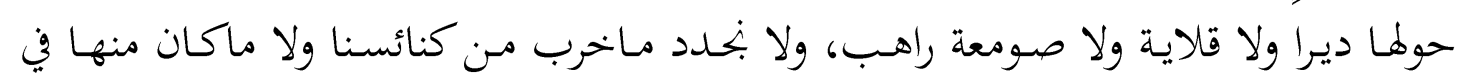
خطط المسلمين، وألا نمنع كنائسنا من المسلمين أن ينزلوها في الليل والنهار، وأن نوسع أبوابها

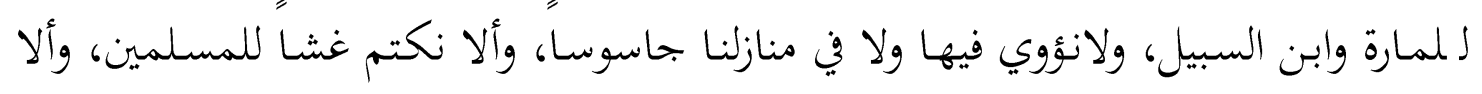
نضرب بنواقيسنا إلا ضرباً خفياً في جوف كنائسنا، ولانظهر عليها صليبا، ولا نرفع أصواتنا في

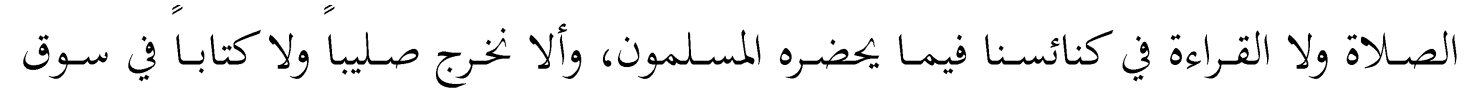

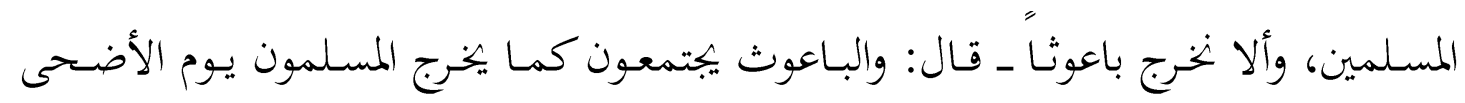

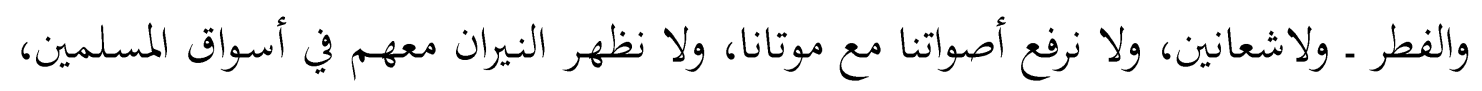

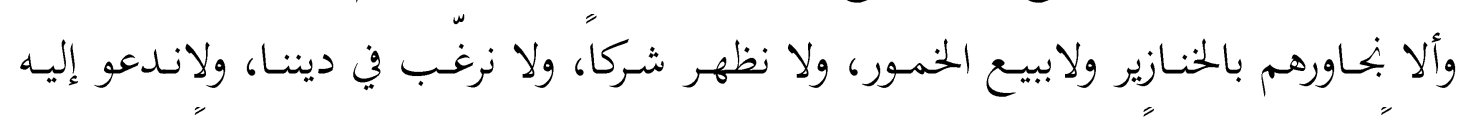

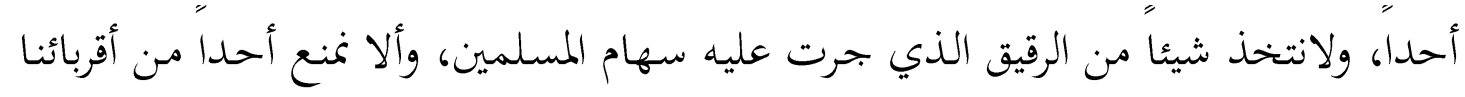

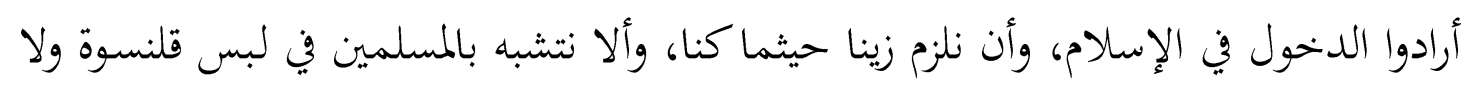

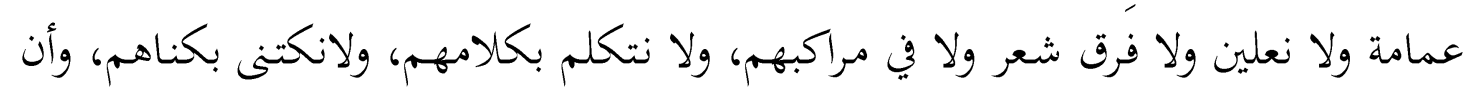

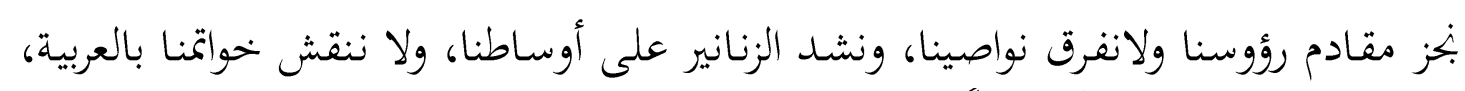

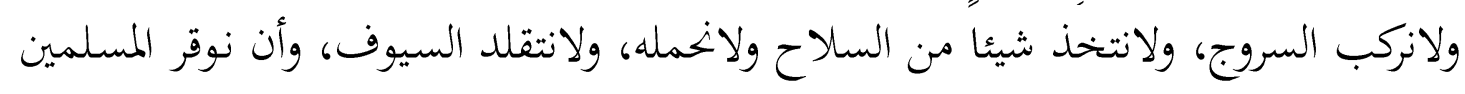

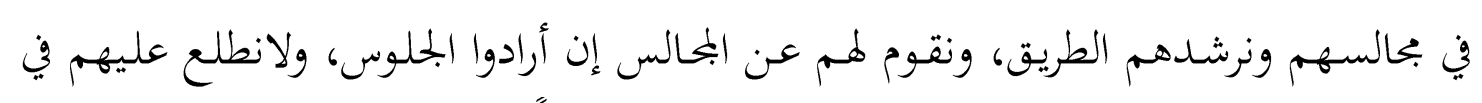

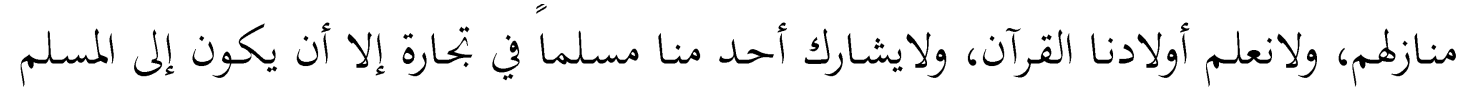

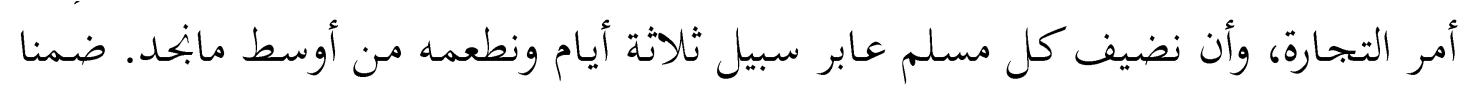

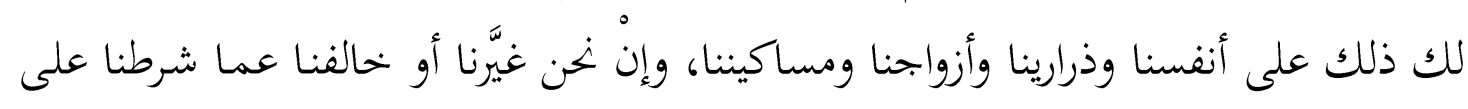

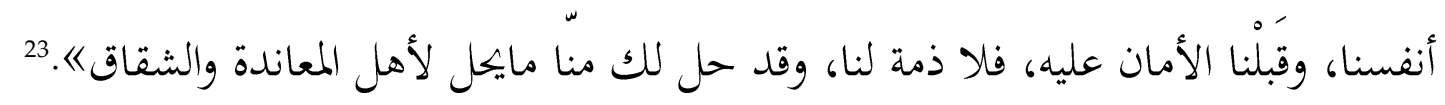
Terjemahnya:

"Abdullāh bin Ahmad berkata, Abu Syurahbil Al-Ḥimși 'Isā bin Khalid 664

${ }^{23}$ Ibn al-Qayȳ̄m al-Jauzī, Aḥkām ahl al-Zimmah, , (Cet. Dāru al 'Ilmi Li al-Malāȳ̄n, 1983 M.), h. 657- 
mengkabarkan kepada kami, dia mengatakan; Umar Abū al-Yamān dan Abū Mugīrah berkata mengkabarkan kepada kami, keduanya berkata; Isma'il bin Iyyāsy mengkabarkan kepada kami, ia berkata; lebih dari seorang ulama' mengkabarkan kepada kami, mereka mengatakan; Penduduk Jazirah menulis shalat kepada 'Abd alRahmān bin Ganam, yang berisi; Sesungguhnya ketika kalian datang ke negeri kami, kami meminta kapada kalian jaminan keamanan untuk nyawa kami dan para pemeluk agama kami, yaitu kami berjanji tidak akan membangun gereja yang berada di dalam negeri kami, juga tidak membangun disekitar gereja biara, tempat uskup dan tempat pendeta, kami tidak akan memperbaharui gereja kami yang roboh dan tidak pula yang menjadi perencanaan orang-orang Islam, kami tidak akan melarang orang Islam untuk singgah di gereja kami baik siang maupun malam, kami akan perluas pintunya bagi orang yang lewan dan musafir, kami tidak akan melindungi seorang mata-mata dalam gereja atau dalam rumah kami, kami tidak menutupi penipuan kepada orangorang Islam, kami tidak akan memukul lonceng kecuali pelan-pelan di dalam gereja kami, kami tidak akan menampakkan salib, kami tidak akan mengeraskan do'a dan bacaan kami di gereja yang dihadiri orang-orang Islam, kami tidak akan mengeluarkan salib dan kitab di pasar orang-orang Islam, kami tidak akan keluar untuk bā'úú - dia berkata; $b \bar{a}^{\prime} \bar{u} \dot{s}$ adalah mereka berkumpul sebagaimana orang-orang Islam pada hari raya 'ìd al-ạ̣a dan 'ìd fiți - dan tidak pula sya'ānīn, kami tidak akan mengeraskan suara kami ketika ada kematian di antara kami, kami tidak menampakkan api bersama mereka di pasar orang Islam, kami tidak akan bertetangga dengan mereka dengan memelihara babi, kami tidak akan menjual khomer, kami tidak akan menampakkan kesyirikan, kami tidak menawarkan agama kami, kami tidak mengajak seseorangpun masuk agama kami, kami tidak akan mengambil budak yang menjadi bagian orangorang Islam, kami tidak akan melarang seorangpun dari kerabat kami yang mau masuk Islam, kami akan selalu mengenakan pakaian kami di manapun kami berada, kami tidak akan menyerupai orang-orang Islam dalam memakai peci, sorban, sandal, membelah rabut dalam bersisir dan kendaraan, kami tidak berbicara dengan bahasa mereka, kami tidak membuat kunniyah (nama sebutan) dengan kuniyah yang mereka gunakan, kami akan memendekkan rambut depan kami dan tidak membelah rambut kami dalam bersisir, kami akan mengenakan sabuk pada tengah badan kami, kami tidak akan mengukir cincin kami dengan menggunakan bahasa arab, kami tidak akan naik kereta kuda, kami tidak akan menyandang dan membawa senjata, kami tidak akan menenteng pedang, kami akan menghormati orang-orang Islam dalam majlis dan menunjukkan jalan kepada mereka, dan kami akan berdiri dalam sebuah majlis jika mereka mau duduk, kami tidak meninggikan rumah kami melebihi rumah mereka, kami tidak akan mengajari Alquran kepada anak-anak kami, kami tidak akan turut campur perdagangan orang muslim kecuali orang muslim tersebut mem butuhkannya, dan kami akan menjamu orang muslim yang dalam perjalanan selama tiga hari dan kami akan menghidangkan makanan yang biasa kami dapatkan. Kami menjamin bahwa kami, anak-anak kami, istri-istri kami dan orang-orang miskin kami 
akan melaksanakan itu semua. Dan jika kami merubah atau menyelisihi syarat-syarat yang telah kami tetapkan kepada diri kami untuk mendapatkan jaminan keamanan, maka tidak ada żimmah lagi bagi kami, dan halal memperlakukan kami sebagaimana memperlakukan orang yang membangkang dan menentang." Maka 'Abd al-Rahmmān bin Ganam menulis surat kepada 'Umar bin al-Khațțāb ra., tentang hal itu. Dalam isi surat itu disebutkan: "Berlakukanlah apa yang mereka minta, dan tambahkan dua huruf pada syarat-syarat yang mereka tetapkan untuk diri mereka sendiri itu, yaitu mereka tidak boleh membeli budak-budak kami (budak muslim) dan barang siapa memukul seorang muslim, ia telah membatalkan janjinya. "Maka 'Abd al-Raḥmān bin Ganam pun melaksanakan nya, dan membiarkan orang Romawi yang tinggal di kotakota Syam dengan syarat-syarat tersebut. Ibn al-Qayyīm berkata: "Kemasyhuran syarat-syarat ini menjadikannya tidak perlu lagi meneliti sanadnya, karena sesungguhnya para ulama' menerimanya dan menyebutkannya dalam kitab-kitab mereka. Mereka berhujjah dengannya dan mereka senantiasa menyebutkan syaratsyarat yang ditetapkan oleh khalifah 'Umar ini dengan lisan dan kitab-kitab mereka. Dan setelah itu para kholifah setelahnya melaksanakannya dan membuat konsekuensikonsekuensinya." 24

3) Hak bekerja dan berusaha; Dalam konteks ini kaum żimmī dibebaskan untuk melakukan dan melaksanakan usaha serta bisnis mereka. Tercatat bahwa sejak masa Rasulullah saw. Kelompok ini telah bebas bergerak melaksanakan bisnis dan perniagaan tanpa batas. Kaun żimmī diberi keleluasaan untuk aktif dalam roda perekonomian, maka tidak heran jika pada masa-masa sesudah Rasul, kaun minoritas ini mampu menguasai beberapa sektor kehidupan kaum muslimin. Sektor yang dimaksud di antaranya adalah farmasi, hal ini terjadi karena kaum muslimin tidak memberi batas terhadap peluang usaha bagi non muslim. ${ }^{25}$

4). Hak atas jaminan hari tua; Tokoh yang paling mencolok dalam pem bicaraan tentang hak-hak ahl al-żimmī dalam komunitas Islam adalah 'Umar bin Khațāā. Figur yang satu ini menetapkan bagian tertentu dari harta Bait al-Māl untuk menyantuni kalangan $\dot{z} i m m \bar{\imath}$ yang mengalami kesulitan hidup serta terpaan usia tua. Khalifah kedua ini memberi dispensasi kepada ahl al-żimmī yang tidak mampu lagi menghidupi dirinya agar diberi tunjangan serta dibebas kan dari pembayaran jizyah. $^{26}$

5) Hak dalam bidang politik; Sebuah hal yang ironis jika mengacu pada hak ini. Kelompok minoritas dari agama lain diberi kesempatan untuk menduduki jabatan tertentu dalam tata kelola kenegaraan. Perjanjian żimmah telah berimplikasi kuat terhadap eksistensi non muslim dalam konteks ini. Perjanjian

24 Terjemahan penulis.

${ }^{25}$ Abul A'la Maududi, Hak-hak Asasi Manusia dalam Islam, Terj. Bambang Iriana Djaja Atmadja, (Jakarta: Bumi Aksara, 2005), h. 33.

26 Ali Abdul Halim Mahmud, Karakteristik Umat Terbaik: Telaah Manhaj, Aqidah, dan Harakah. Diterjemahkan dari Ma'a al-Aqidah wa al-Harakah, wa al-Manhaj fi Khairi Ummatin Ukhrijat li al-Nas oleh As'ad Yasin. (Jakarta: Gema Insani Press. 1996), h. 139-144 
yang mengisyaratkan ikatan yang kuat dan disandarkan kepada Allah dan Rasul-Nya.

Dispensasi ini menjadi bukti akan sikap toleransi umat Islam terhadap penganut agama lain guna memberi mereka ketentraman dan kebebasan hidup di tengah kaum muslimin. Sebuah fenomena yang mungkin akan sulit didapati dalam ajaran agama lain. Islam telah memberikan imbal terhadap perjanjian kuat żimmah dengan pemberian keleluasaan dan jaminan keamanan serta kebebasan ikut berpartisipasi dalam politik internal kaum muslimin. Sebuah gambaran ketulusan dan kebesaran hati mereka terhadap kelompok minoritas yang ada dalam perlindungan mereka. ${ }^{27}$

Dalam catatan Abū al-A'lā al-Maudūdī, seluruh jabatan politik dapat diberikan kepada kelompok minoritas kecuali sedikit pada jabatan strategis dan berkiatan lansung dengan hajat hidup masyarakat. Jabatan dimaksud meliputi syūra dan kepala Negara. Jabatan ini berkitan lansung dengan kesejahteraan rakyat dan titik penentu dari arah kebijakan bernegara. ${ }^{28}$ Pada jabatan selain kedua jabatan sentral tadi, Abū al-A'lā al-Maudūdī memboleh kan kaum żimmī menduduki jabatan semisal jabatan jawatan administrasi Negara sepanjang jabatan tersebut tidak menjadi central urusan public dalam tata kelola pemerintahan dalam Islam. $^{29}$

Wajah perpolitikan yang sangat akomodatif dipraktekkan oleh kaum muslimin dengan mencontoh dari sikap dasar yang dicerminkan Nabi kepada ummatnya. Beberapa setting peristiwa antara Rasulullah saw. dengan penganut agama lain semisal Yahudi dan Nasrani serta kaum musyrikin, telah menjadi pegangan kaum muslimin dalam menyikapi hegemonitas warga Negara Madinah. Sikap terbuka menerima penganut agama lain di tengah kaum muslimin telah merasuk ke sanubari mereka sehingga tanpa tawar menawar mereka mempraktekkan bentuk solidaritas mereka kepada penganut agama lain. Patut pula diperhatikan bahwa keberadaan kelompok agama lain dalam struktur masyarakat Islam Madinah merupakan sebuah kekuatan tersendiri dalam menciptakan masyarakat yang adil dsn makmur. Setidaknya, kaum muslimin telah memperlihatkan contoh berkehidupan masyarakat yang majemuk dan serba beragama. Keragaman itulah yang membuat mereka menjadi sangat terbuka kepada penganut agama lain semisal penganut agama Yahudi dan Nasrani. Kedua penganut agama ini kemudian dikenal dengan ahl al-kitāb, meski ada kelompok berbeda yang menyatakan bahwa termasuk dalam kategori ini adalah

27 Musțafa al-Siba'i, Sistem Masyarakat Islam, (Jakarta: Pustaka al-Hidayah, 1987), h. 182; Imam Munawwir, Sikap Islam terhadap Kekerasan, Damai, Toleransi, dan Solidaritas, (Surabaya: Bina Ilmu, 1984), h. 58-59.

${ }^{28}$ Abul A'la Maudūdi, Hukum dan Konstitusi Sistem Politik Islam, Terj. Asep Hikmat, Bandung: Mizan, Cet. VI, 1998), 309.

${ }^{29}$ Abū al-A'lā al-Maudūdī, Hukum dan Konstitusi Sistem Politik Islam, h. 310. 
mereka yang beragama Majuzi. ${ }^{30}$

Pada sisi lain, kaum ahl żimmī juga memiliki beberapa kewajiban yang harus mereka tetap jaga dan amalkan, diantara kewajiban-kewajiban tersebut adalah sebagai berikut;

1. Diwajibkan kepada mereka untuk membayar jizyah kecuali kepada beberapa golongan di antara (1) kaum perempuan, (2) anak laki-laki yang belum dewasa, (3) orang lanjut usia, (4) orang cacat karena suatu penyakit (zamin), (5) orang lumpuh , (6) orang buta (7) orang melarat ( faqir ) yang tak mampu berusaha (ghairai-mu'tamil), (8) budak belian, (9) budak belian yang bekerja untuk memerdekakan sendiri (mudbir), dan (10) para rahib. ${ }^{31}$

2. Diwajibkan untuk senantiasa menjaga konstitusi Negara Islam dan perasaan umat Islam dengan cara menjaga tatakrama berkehidupan mereka. Mereka dihimbau untuk berpakaian selayaknya dan tidak meniru umat Islam guna mengaburkan identitas mereka. ${ }^{32}$

3. Mereka tetap diwajibkan untuk menjaga sikap dan tingkahlaku mereka yang berkenaan dengan agama mereka. Meski mereka dibolehkan untuk meminum khamar di Negara muslim namun mereka dilarang keras untuk memasarkannya. Ijin untuk mengkomsumsi minuman keras hanya berlaku pada tempat privat dan tidak berlaku di depan umum apalagi mengajak muslim lainnya untuk mengkomsumsinya.

\section{KESIMPULAN}

Kelompok ahl al-żimmī merupakan kelompok minoritas dalam Islam yang mendapat keistimewaan tertentu. Keistimewaan ini disebabkan karena mereka mengadakan perjanjian yang sangat kuat żimmah dengan Negara Islam. Selanjutnya, aqd żimmah yang mereka ikrarkan sekaligus mewajibkan mereka untuk membayar jizyah, sebuah pembayaran yang dibayarkan sekali setahun.

Perjanjian żimmah membawa pengaruh terhadap hak dan kewajiban mereka di tengah komunitas muslim. Salahsatu hak yang patut mendapat perhatian adalah hak mereka berkenaan dengan kebolehan mereka menjadi pejabat Negara tanpa batas kecuali pada jabatan-jabatan prinsip dan berkaitan dengan hajat hidup lansung kaum muslimin. Dalam memperoleh hak mereka, kelompok ini diwajibkan untuk menjaga beberpa hal yang berkaitan dengan kaidah hidup mereka dalam masyarakat muslim semisal larangan memasarkan miras dan mengajak warga muslim untuk mencicipi atau meminum minuman keras.

${ }^{30}$ Adian Husaini dan Nuin Hidayat, Islam Liberal, Sejarah Konseps, Penyimpangan dan Jawaban (Cet. 1, Gema Insani Press, Jakarta: 2002), h. 55-60.

31 Muhammad Iqbal, Fiqh Siyasah Kontekstualisasi Doktrin Islam, (Jakarta: Gaya Media Pratama, 2001), h. 278; Adiwarman Azwar Karim, Sejarah Pemikiran Ekonomi Islam, (Jakarta : III IT, Cet. II), h. 31.

${ }^{32}$ Lihat kembali footnote 25 hal. 12. 


\section{Daftar Pustaka}

Ibn Hisyām, Al-Sīrah al-Nabawiyyah, Tahqīq: Musțafa al-Saqa', Jilid 1, (Mesir: Musțafa al-Bābi al-Hilyi, Cet. 2, 1375 H/ 1955 M)

'Abd al-Salāmm Ja'far dan Aḥmad al-Syaikh, Al-Muslimūn wa al-Ākhar: Usus li Tabādu al-Hivwār wa al-Ta'āwun al-Silmi, (Kairo: Rābițah al-Jāmi' ah al-Islāmiyah, 2006)

al-Jauzī, Ibn al-Qayyīm, Aḥkām ahl al-Żimmah, (Cet. Dāru al 'Ilmi Li al-Malāyīn, 1983 M.)

al-Mubarakfury, Saifurrahman, Sīrah Nabawiyyah, (Jakarta: Pustaka al-Kausar, Cet. 19, 2005)

al-Qalibi, Al-Syadzili, Ahl al-Żimmah fì al-Haḍārah al-Islāmiyah, (Beirut: Dār al-Gharb al-Islāmi, 1998),

al-Qarḍāwi, Yusuf, Ghair al-Muslimīn fì al-Mujtama' al-Islāmiy, (Kairo: Maktabah Waḥbah, Cet. ke-3, 1413 H/ 1992 M)

al-Qarḍāwi, Yūsuf, Ghair al-Muslimīn fì al-Mujtama' al-Islāmiy, (Kairo: Maktabah Wahbah, Cet. ke-3,1992 M)

al-Qarḍawi,Yūsuf, Al-Halāl wa al-Harām fì al-Islām, (Kairo: Maktabah Wahbah, Cet. 22, $1997 \mathrm{M})$

al-Qardhawi, Yusuf, Fikih Jihad: Sebuah Karya Monumental Terlengkap tentang Jihad menurut al-Qur'an dan Sunnah, Terj. Irfan Maulana Hakim, (Bandung: Mizan, 2010)

al-Sibā'i, Musțafa, Sistem Masyarakat Islam, (Jakarta: Pustaka al-Hidayah, 1987)

Munawwir, Imam, Sikap Islam terhadap Kekerasan, Damai, Toleransi, dan Solidaritas, (Surabaya: Bina Ilmu, 1984).

al-Zabidi, Muhammad Murtaḍa al-Husaini, Tāj al-'Arūs min Jawāhir al-Qāmūus, Jilid 28, (Kuwait: Hukūmah al-Kuwait, 1385 H/ 1965 M)

al-Zawi, Al-Ṭāhir Ahmad, Al-Qāmūs al-Muhīt , Jilid 2, (Saudi: Dār 'Alam al-Kutub li al-Nasyr wa al-Tawzī', 1417H/1996M)

Anas, Malik ibn, Al-Muwatța', Juz: 2, (T. T: Muassasah Zayid ibn Sulman al-Nahyan, Cet. 1, 1425)

An-Naim, Abdullahi Ahmed,. Islam dan Negara Sekuler: Menegosiasikan Masa Depan Syariah. (Bandung: Mizan, 2007)

Azwar Karim, Adiwarman, Sejarah Pemikiran Ekonomi Islam, (Jakarta : III IT, Cet. II)

Cawidu, Harifuddin,. Konsep Kufr dalam Al-Qur'an. (Jakarta: Bulan Bintang, 1991)

Haq, Hamka, Islam Rahmah untuk Bangsa, (Cet. I; Jakarta: PT. Wahana Semesta Intermedia; 2009)

Haq, Hamka,. Konsep Zimmi dalam Islam dalam, Lutfi Asyaukanie, Wajah Liberal Islam di Indonesia. (Jakarta : JIL, 2002)

Husaini, Adian dan Nuin Hidayat, Islam Liberal, Sejarah Konseps, Penyimpangan dan Jawaban (Cet. 1, Gema Insani Press, Jakarta: 2002)

Ibn Manżūr, Lisān al-'Arab, Jilid 3, (Kairo: Dār al-Hadīì, 2003)

Iqbal, Muhammad, Fiqh Siyasah Kontekstualisasi Doktrin Islam, (Jakarta: Gaya Media 
Pratama, 2001)

Kementerian Agama RI., Alquran dan Terjemahnya (Semarang, PT. Karya Toha Putra, 1998)

Madjid, Nurcholis, Zainun Kamal dkk,. Fiqih Lintas Agama: Membangun Masyarakat Inklusif-Pluralis. (Jakarta: Yayasan Wakaf Paramadina dan The Asia Foundation, 2004)

Mahmud, Ali Abdul Halim, Karakteristik Umat Terbaik: Telaah Manhaj, Aqidah, dan Harakah. Diterjemahkan dari Ma'a al-Aqidah wa al-Harakah, wa al-Manhaj fi Khairi Ummatin Ukhrijat li al-Nas oleh As'ad Yasin. (Jakarta: Gema Insani Press. 1996)

Maudūdi Abul A'lā, Hak-hak Asasi Manusia dalam Islam, Terj. Bambang Iriana Djajatmadja, (Jakarta: Bumi Aksara, 2005)

Maudūdi, Abul A'la, Hukum dan Konstitusi Sistem Politik Islam, Terj. Asep Hikmat, Bandung: Mizan, Cet. VI, 1998)

Sjadzali Munawir Sjadzali, Islam dan Negara, (Cet. V; Jakarta: UI Press, 1993)

Wehr, Hans. English Arabic Language Dictionaries. (Itacha New York: Spoken Language Service, Inc. 1976) 